DOI: $10.4274 /$ tod.galenos.2018.43255

Turk J Osteoporos 2018;24:73-7

\title{
Impact of Neuropathic Pain on Health-Related Quality of Life and Disability in Patients with Chronic Low Back Pain
}

\author{
Kronik Bel Ağrılı Hastalarda Nöropatik Ağrının Sağlıkla Ilişkili Yaşam Kalitesi ve Özürlülük \\ Üzerine Etkisi \\ Bilge Kesikburun, (D) Nihal Tezel, (D) Nuray Gülgönül, (D) Emel Ekşioğlu, (D) Aytül Çakcı \\ University of Health Sciences, Dışkapı Yıldırım Beyazıt Training and Research Hospital, Clinic of Physical Medicine and Rehabilitation, Ankara, Turkey
}

\section{Abstract}

Objective: Low back pain (LBP) is the most common chronic pain disorder worldwide. Chronic LBP is a mixed pain syndrome associated with nociceptive and neuropathic pain mechanisms. Investigation and early treatment of neuropathic pain is important in the management of chronic LBP. The aim of this study is to investigate the frequency of neuropathic pain and determine its impact on health-related quality of life and disability in patients with chronic LBP.

Materials and Methods: A total of 120 patients with chronic LBP participated in the study. The presence of neuropathic pain was assessed using Leeds Assessment of Neuropathic Symptoms and Signs pain scale. 10-cm visual analogue scale (VAS) pain score, Oswestry Disability index (ODI) and short form-36 (SF-36) measurements were performed. Predictors for the presence of neuropathic pain were also investigated. Results: Neuropathic pain was detected in 49 (40.8\%) of the patients with chronic LBP. ODI score and VAS pain score in patients with neuropathic pain were higher than that in those without neuropathic pain $(p<0.001$ and $p=0.035$, respectively). Physical function, body pain, general health and physical component subscales of SF-36 were lower in patients with neuropathic pain $(p=0.043, p<0.001, p=0.012$, $p<0.001$, respectively). Advanced age and radicular LBP were found as predictors for neuropathic pain ( $p=0.016$ and $p<0.001$, respectively). Conclusion: The presence of neuropathic pain in chronic LBP was found relevant with poor health-related quality of life and disability. Advanced age and presence of radicular pain were associated with neuropathic involvement.

Keywords: Chronic low back pain, neuropathic pain, disability, quality of life

\section{Öz}

Amaç: Bel ağrısı dünya çapında en yaygın kronik ağrı bozukluğudur. Kronik bel ağıısı nosiseptif ve nöropatik mekanizmalarla ilişkili olan mikst bir ağrı sendromudur. Nöropatik ağrının araştırıması ve erken tedavisi kronik bel ağrııının yönetiminde öneme sahiptir. Bu çalışmanın amacı kronik bel ağrılı hastalarda nöropatik ağrı sıklığını araştırmak ve sağılıkla ilişkili yaşam kalitesi ve özürlülük üzerine etkisini belirlemektir.

Gereç ve Yöntem: Toplam 120 kronik bel ağrıı hasta çalışmaya katıldı. Nöropatik ağrının varlığı Leeds Assessment of Neuropathic Symptoms and Signs kullanılarak değerlendirildi. $10 \mathrm{~cm}$ vizüel analog skala (VAS) ağrı skoru, Oswestry Özürlülük indeksi (ODi) ve kısa form-36 (KS-36) Ölçümleri yapıldı. Ayrıca nöropatik ağıı için prediktörler araştırıldı.

Bulgular: Kronik bel ağrılı hastaların 49'unda $(\% 4,8)$ nöropatik ağrı tespit edildi. ODi skoru ve VAS ağrı skoru nöropatik ağrısı olanlarda nöropatik ağrısı olmayanlara göre daha yüksekti (sırasıyla $p<0,001$ ve $p=0,035$ ). Nöropatik ağrısı olan hastalarda KS-36'nın fiziksel fonksiyon, vücut ağrısı, genel sağlık ve fiziksel komponent alt birimleri daha düşüktü (sırasıyla $p=0,043 ; p<0,001 ; p=0,012 ; p<0,001$ ). İleri yaş ve radiküler bel ağrısı nöropatik ağrı için belirleyiciler olarak bulundu (sırasıyla $p=0,016$ ve $p<0,001$ ).

Sonuç: Kronik bel ağrısında nöropatik ağrının varlığı düşük yaşam kalitesi ve özürlülük ile ilişkili bulundu. ileri yaş ve radiküler ağrının varlığı nöropatik tutulumla ilişkiliydi.

Anahtar kelimeler: Kronik bel ağrısı, nöropatik ağrı, özürlülük, yaşam kalitesi

\section{Introduction}

Low back pain (LBP) is the most common chronic pain disorder worldwide, effecting $60-85 \%$ of the adult population (1). Chronic LBP is also the most common cause of work disability in young population (2). It was found related with poor quality of life and elevated healthcare costs (3). The economic burden of LBP has increased gradually each year (3).

The underlying pathophysiological mechanism of chronic LBP is complex and heterogeneous. Its mechanism can be subdivided

Address for Correspondence/Yazıșma Adresi: Bilge Kesikburun MD, University of Health Sciences, Dışkapı Yıldııım Beyazıt Training and Research Hospital, Clinic of Physical Medicine and Rehabilitation, Ankara, Turkey Phone: +90 5055847706 E-mail: drbilgekb@gmail.com ORCID ID: orcid.org/0000-0001-6110-2252 Received/Geliş Tarihi: 05.07.2018 Accepted/Kabul Tarihi: 12.12.2018

${ }^{\oplus}$ Copyright 2018 by the Turkish Osteoporosis Society Turkish Journal of Osteoporosis published by Galenos Yayınevi. 
into two broad pain categories: neuropathic pain (nervous system-injury) and nociceptive pain (tissue-injury) (4). In new concepts for understanding of chronic LBP, it is assumed as a mixed pain syndrome which both nociceptive and neuropathic pain mechanisms involve in. The Neuropathic Pain Special Interest Group of the International Association for the Study of Pain described neuropathic pain as "pain arising as direct consequence of a lesion or disease affecting the somatosensory system" (5). Chronic LBP with neuropathic involvement is one of the most frequent neuropathic pain conditions. Prevalence of neuropathic pain in chronic LBP has been found varying from $16 \%$ to $55 \%$ depending on the method used in the studies (6-9). There is a significant socio-economic burden associated with neuropathic involvement in chronic LBP. Neuropathic component was showed accounting for $96 \%$ of the total cost in chronic LBP (10). Cost of care/patient was found $160 \%$ higher in chronic LBP patients with neuropathic pain than in those without neuropathic pain (10). So diagnosis and early treatment of neuropathic pain is of importance in the management of chronic LBP.

The negative impact of chronic LBP on disability and quality of life is a well-known issue. However, few studies have evaluated the association between neuropathic pain and disability or quality of life in chronic LBP. The aim of this study was to evaluate the frequency of neuropathic pain and determine its impact on disability, health related quality of life, and severity of pain in patients with chronic LBP.

\section{Materials and Methods}

\section{Patients}

A cross-sectional study was undertaken in the Department of Physical Medicine and Rehabilitation, Dışkapı Yıldırım Beyazıt Research and Training Hospital. A total of 120 patients with chronic LBP who visited the outpatient clinic between May 2016 to November 2016 were enrolled for the study. The inclusion criteria were 1) presence of LBP with or without associated leg pain or numbness; 2) LBP lasting more than 3 months; 3) aging between 18 and 65 years. The exclusion criteria were 1) history of low back surgery; 2) LBP combined with inflammatory diseases, vertebral fracture, spine infection, tumors; 3) diagnosed as having polyneuropathy; 4) uncontrolled systemic medical disease such as cardiac, diabetes mellitus, chronic renal failure; 5) deterioration of the cognitive functions necessary to fulfill the questionnaires. The study protocol was approved by the Local Research Ethics Committee of Dışkapı Yıldırım Beyazıt Research and Training Hospital (date: 25.04.2016 and number: 29/16). The study adhered to the guidelines of the Declaration of Helsinki and informed consent was provided from all the participants.

\section{Outcome Measures}

Leeds assessment of neuropathic symptoms and signs (LANSS) pain scale was used to determine the presence of neuropathic pain. LANSS pain scale consists of 7 items. There are five questions about the sensory experiences including dysesthesia, autonomic dysfunction, evoked pain, paroxysmal pain and thermal pain during the last week and two sensory examination items including allodynia and pinprick threshold. Total score is ranged between 0-24 points. A score equal to or above 12 points indicates neuropathic pain. The validity and reliability of the Turkish version of LANSS pain scale has been performed (11). The patients were assigned to two groups according to LANSS pain scale: the patients with neuropathic pain (neuropathic group) or the patients without neuropathic pain (non-neuropathic group).

Demographics of the patients including age, gender, body mass index (BMI), education period, history of smoking, marital status were collected by face to face interviews. Pain duration, which was regarded as chronic if more than three months, was questioned. Location of the LBP was recorded as axial (pain without lower limb radiation) and or radicular (pain with lower limb radiation). Severity of pain was assessed by using the visual analogue scale (VAS) ranging from $0 \mathrm{~cm}$ (no pain) to 10 $\mathrm{cm}$ (worst pain). The VAS pain score was defined as mild pain ranged from 0-4, moderate from 5-7 and severe from 8-10 (12). The disability related to LBP was evaluated with LBP Oswestry Disability index (ODI) as a disease-specific functional status questionnaire. It consists of 10 questions. Each question is rated on a scale from 0 to 5 points. The ODI score ranges from 0 to 50 , with a higher score indicating higher disability. The Turkish validity and reliability of ODI have been shown (13).

Health-related quality of life was assessed by the Turkish version of the item short form-36 health survey (SF-36) (14). The SF-36 assesses eight health concepts: physical functioning, role limitations-physical, bodily pain, general health, vitality, social functioning, role limitations-emotional, and mental health, which are summarized in two component score; physical component summary and mental component summary. SF-36 scales are standardized to a range from 0 to 100 with a higher score indicating better health status.

\section{Statistical Analysis}

Data are presented as mean \pm standard deviation for continuous variables and as proportions for categorical variables. Chi-square test was applied for comparison of proportions. The Student t-test was used to compare mean values of continuous variables between the groups. If the distribution of the continuous variables was not normal, the Mann-Whitney $U$ test was used for comparison. Multiple logistic regression analysis was conducted to identify the predictors for the neuropathic pain. Univariate analysis was utilized first between each predictor and presence of neuropathic pain to identify the variables that were included in the multivariate model. Those variables with $p<0.20$ in univariate analysis and identified individually as significant predictor were entered into the multivariate model. The stepwise method was used to compare the influence of different factors and types of factors on the presence of 
neuropathic pain. The level of significance was set at $p<0.05$ SPSS for Mac, Version 20.0 was used for the statistical analyses (SPSS, Chicago, IL).

\section{Results}

One hundred twenty patients (mean age, $44.0 \pm 10.8$ years) were enrolled for the study. There were 27 male $(22.5 \%)$ and 93 female $(77.5 \%)$ patients in the study. The mean duration of LBP was $5.3 \pm 5.5$ years 32 patients (26.7\%) had axial LBP and 88 patients (73.3) had radicular pain. There was neuropathic pain in 49 patients (40.8\%). All demographic and clinical characteristics of the patients are presented in Table 1.

Table 2 presents the results of comparison of demographic and clinical parameters between the patients with and without neuropathic pain. The age and BMl were higher in the neuropathic group in comparison with the non-neuropathic group ( $p=0.038$ and $p=0.052$, respectively). The proportion of radicular pain was $91.8 \%$ in the neuropathic group and significantly higher than the non-neuropathic group $(p<0.001)$. The VAS score and ODI score were significantly increased in the neuropathic group $(p<0.035$ and $p<0.001$, respectively) (Figure 1).

Physical function, body pain, general health subscales and

\section{Table 1. Demographic and clinical characteristics of the patients with} chronic low back pain

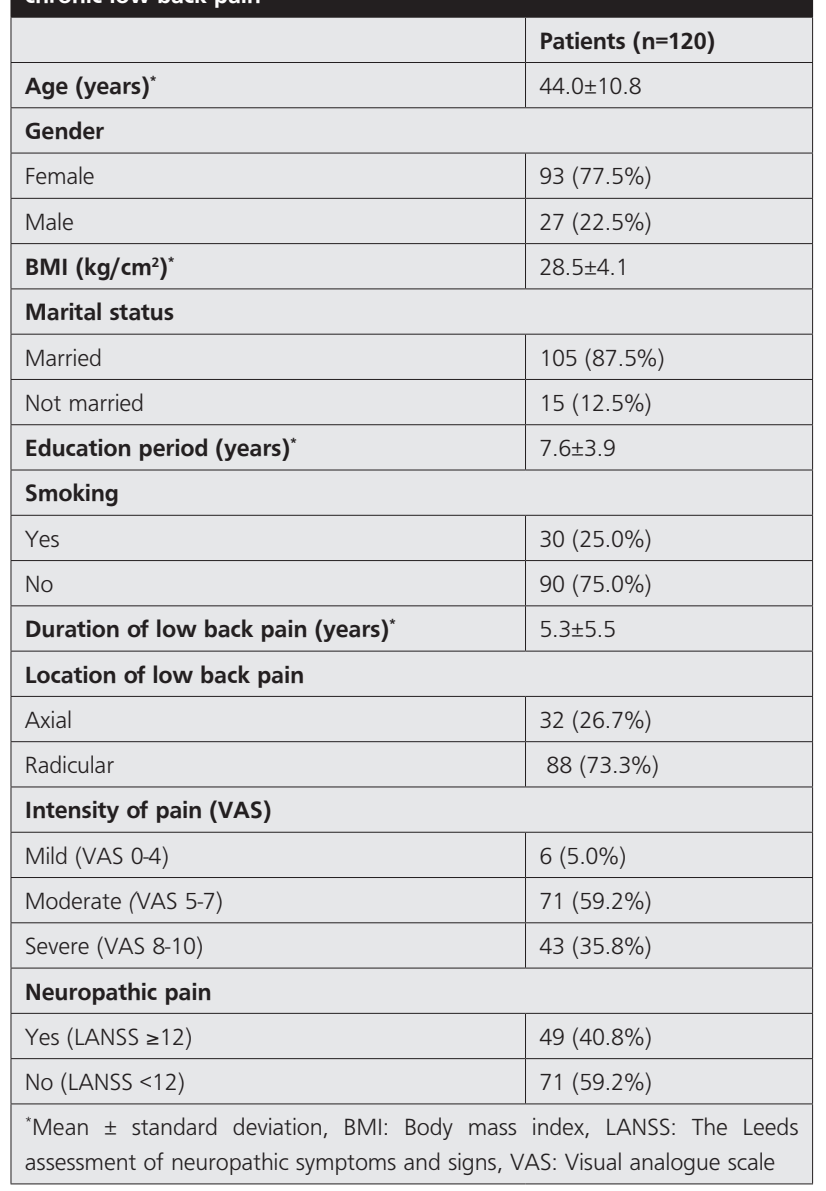

physical component scores of SF-36 were lower in the neuropathic group compared to the non-neuropathic group ( $p=0.043, p<0.001, p=0.012$, and $p<0.001$, respectively) (Table 3). Age, BMI and radicular pain were identified as factors related to LBP in the univariate analysis and included in the multivariate model. Multiple logistic regression analysis revealed that increase in age and presence of radicular pain were significant independent predictors for neuropathic pain in patients with chronic LBP ( $p=0.046$ and $p<0.001$; respectively) (Table 4).

\section{Discussion}

This study investigated the frequency of neuropathic pain and its impact on disability and quality of life in patients with LBP. The study showed that $40.8 \%$ of the patients with LBP have neuropathic pain as screened by the LANSS questionnaire. Comparison of the neuropathic group and non-neuropathic group revealed that the patients with neuropathic pain have significantly poor quality of life. In addition, the patients with neuropathic pain confronted higher pain level and disability scores. Advanced age and radicular pain were found associated with presence of neuropathic pain.

The prevalence of neuropathic pain is approximately $3 \%-6 \%$ in general population. However, neuropathic pain prevalence is much higher in patients with chronic LBP compared to general population. El Sissi et al (15) found that 55\% of the patients

\begin{tabular}{|c|c|c|c|}
\hline & $\begin{array}{l}\text { Patients with } \\
\text { neuropathic } \\
\text { pain }(n=49)\end{array}$ & $\begin{array}{l}\text { Patients } \\
\text { without } \\
\text { neuropathic } \\
\text { pain }(n=71)\end{array}$ & p \\
\hline Age (years) ${ }^{\star}$ & $46.5 \pm 10.4$ & $42.3 \pm 10.8$ & 0.038 \\
\hline \multicolumn{3}{|l|}{ Gender } & 0.648 \\
\hline Female & $39(41.9 \%)$ & $54(58.1 \%)$ & - \\
\hline Male & $10(37.0 \%)$ & $17(63.0 \%)$ & - \\
\hline BMI $\left(\mathrm{kg} / \mathrm{cm}^{2}\right)^{*}$ & $29.4 \pm 3.9$ & $27.9 \pm 4.0$ & 0.052 \\
\hline \multicolumn{3}{|l|}{ Marital status } & 0.528 \\
\hline Married & $44(41.9 \%)$ & $61(58.1 \%)$ & - \\
\hline Not married & $5(33.3 \%)$ & $10(66.7 \%)$ & - \\
\hline Education period (years) & $7.4 \pm 3.9$ & $7.8 \pm 3.9$ & 0.612 \\
\hline \multicolumn{3}{|l|}{ Smoking } & 0.592 \\
\hline Yes & $11(36.7 \%)$ & $19(63.3 \%)$ & - \\
\hline No & $38(42.2 \%)$ & $52(57.8 \%)$ & - \\
\hline $\begin{array}{l}\text { Duration of low back } \\
\text { pain (years) }\end{array}$ & $6.0 \pm 5.7$ & $4.8 \pm 5.3$ & 0.243 \\
\hline \multicolumn{3}{|l|}{ Location of low back pain } & $<0.001$ \\
\hline Axial & $4(8.2 \%)$ & $28(39.4 \%)$ & - \\
\hline Radicular & $45(91.8 \%)$ & $43(60.6 \%)$ & - \\
\hline Pain intensity (VAS) & $7.20 \pm 1.8$ & $6.54 \pm 1.3$ & 0.035 \\
\hline Oswestry Disability index & $26.9 \pm 8.8$ & $19.6 \pm 7.9$ & $<0.001$ \\
\hline \multicolumn{4}{|c|}{ "Mean \pm standard deviation, BMI: Body mass index, VAS: Visual analogue scale } \\
\hline
\end{tabular}




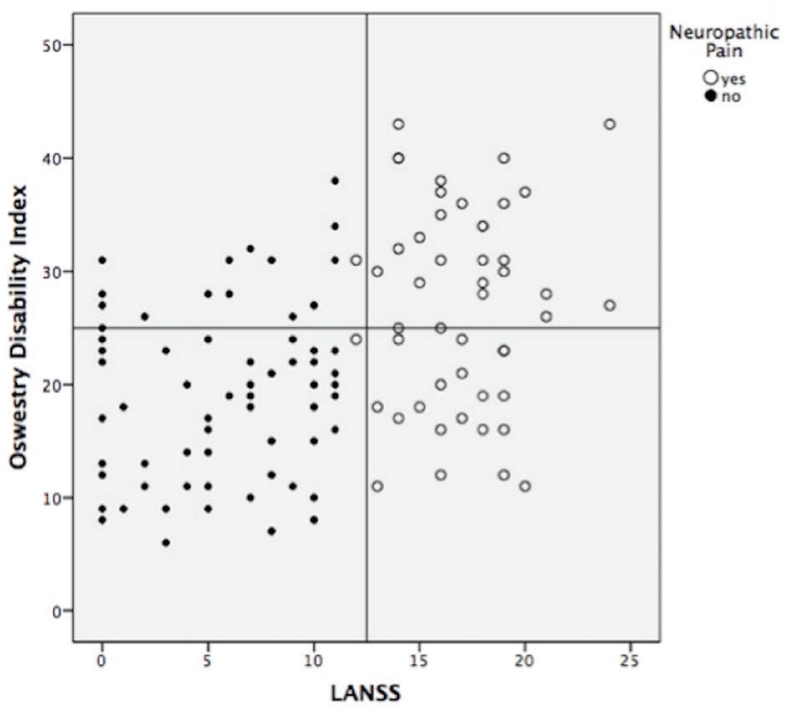

Figure 1. Distribution of ODI scores according to LANSS

\begin{tabular}{|c|c|c|c|}
\hline & $\begin{array}{l}\text { Patients with } \\
\text { neuropathic pain } \\
(n=49)\end{array}$ & $\begin{array}{l}\text { Patients without } \\
\text { neuropathic pain } \\
(\mathrm{n}=71)\end{array}$ & $\mathbf{p}$ \\
\hline Physical function & $29.9 \pm 8.0$ & $43.1 \pm 14.5$ & 0.043 \\
\hline Physical role & $33.4 \pm 8.9$ & $35.2 \pm 10.5$ & 0.339 \\
\hline Body pain & $30.7 \pm 7.7$ & $35.9 \pm 6.9$ & $<0.001$ \\
\hline General health & $35.8 \pm 8.0$ & $39.9 \pm 9.1$ & 0.012 \\
\hline Vitality & $41.9 \pm 8.4$ & $43.2 \pm 8.2$ & 0.384 \\
\hline Social function & $36.6 \pm 9.8$ & $38.0 \pm 9.4$ & 0.436 \\
\hline Emotional role & $35.1 \pm 9.8$ & $37.5 \pm 12.4$ & 0.262 \\
\hline Mental health & $37.6 \pm 11.6$ & $39.4 \pm 9.9$ & 0.390 \\
\hline PCS & $28.8 \pm 7.1$ & $34.8 \pm 8.1$ & $<0.001$ \\
\hline MCS & $41.7 \pm 9.0$ & $41.5 \pm 8.3$ & 0.937 \\
\hline \multicolumn{4}{|c|}{$\begin{array}{l}\text { *Mean } \pm \text { standard deviation, PCS: Physical component summary, MCS: Menta } \\
\text { component summary }\end{array}$} \\
\hline
\end{tabular}

Table 4. Risk factors for neuropathic pain in patients with low back pain (multiple logistic regression)

\begin{tabular}{|l|l|l|}
\hline Factors & $\mathbf{p}$ & $\beta$ \\
\hline Age & $\mathbf{0 . 0 4 6}$ & 0.041 \\
\hline BMI & 0.428 & 0.043 \\
\hline Radicular pain & $<0.001$ & 2.102 \\
\hline BMI: Body mass index & \multicolumn{2}{|l}{} \\
\hline
\end{tabular}

with LBP suffered from neuropathic pain. As a comparable result, the present study showed that the frequency of neuropathic pain was $40.8 \%$ in chronic LBP.

Neuropathic pain is a frequent problem causing higher disability level and poor quality of life in chronic LBP. The diagnosis of neuropathic pain remains challenging due to lack of a gold standard way. Its diagnosis is primarily based on clinical examination and history. Quantitative sensory testing may support the diagnosis by providing extra information. The screening tools which are used to the diagnosis of neuropathic pain are simple and useful in clinical practice. But they are not a substitute for the clinical examination (8). The present study focused on determining the neuropathic pain on the use of LANSS pain scale which was also used in some previous studies of chronic LBP (15-17).

Perception of pain is subjective, so it depends on person. Intensity of pain is affected with some factors such as mental, environmental, burden of disease, increasing age, kind of pain. One of the remarkable findings in the current study was that the patients who had neuropathic pain suffer higher pain level than the patients who had not neuropathic pain. Similarly, Beith et al (9) conducted a study in 343 patients with LBP to evaluate neuropathic pain and found that neuropathic group had higher pain level compared to the non-neuropathic group. Similarly, Freynhagen et al. (18) found that neuropathic pain patients had more severe pain with significantly higher current, average and worst pain scores on the VAS.

The impact of chronic LBP on disability is a well-known issue. The present study showed the LBP patients with neuropathic pain had worse disability scores. Comparable to this finding, in previous studies $(9,19)$, it was showed that the patients who had neuropathic pain had higher-level disability score. Additionally, some previous studies $(7,10,20)$ revealed that the patients with neuropathic pain exploit health resources more than those without neuropathic pain. This findings indicated the negative impact of neuropathic pain not only on functionality of the patients but also cost of chronic LBP. Therefore, the treatment of the neuropathic pain is essential.

This study focused also on impact of neuropathic pain on quality of life. The findings indicated fundamental distinction that the patients with neuropathic pain confronted poorer quality of life than the patients without neuropathic pain. Physical function, body pain, general health domains and physical component scores of SF-36 were significantly lower in patients with neuropathic pain. According to the present findings, presence of neuropathic pain was not associated with mental health. Its effect might be only on physical well-being. Inconsistently, Beith et al. (9) reported that mental and physical component domains were both significantly lower in patients with neuropathic pain. Similar to the present study, Jensen et al. (21) found weak association between neuropathic pain and quality of life domain including mental components. The patients who had chronic pain may cope with physical problems causing disability.

In evaluation of the risk factors for neuropathic pain, radicular pain and increased age were found as risk factors. Radicular pain is common in patients with LBP. In parallel to the present results, presence of leg pain or radiating pain is seen as a specific indicator for patients classified as having neuropathic components by Beith et al. (9). However, it may not be a sensitive predictor for neuropathic pain. The axial pain may also show neuropathic component in LBP (8). Conducting a study to distinguish neuropathic pain in chronic LBP, Kaki et al. (6) found that advanced age, female sex and smoking 
were associated with neuropathic pain. In this study, some well-known risk factors such as smoking, high BMI, female gender and educational level were not found associated with neuropathic pain.

\section{Study Limitations}

There were some limitations of this study. First of all, it was designed as a cross sectional study. The cross sectional design did not allow the causality of the associations to be examined. Secondly, etiology of LBP was not determined. The impact of different causes of LBP on study parameters may vary. Thirdly, LANSS as a screening tool may help to identify the potential patients with neuropathic component. But it would better evaluate the patients with chronic LBP with physical examination and somatosensory function assessment. It might be a limitation for the present study. Finally, the study sample size should have been larger and it might limit to able to determine significant correlations. Further studies with larger sample size and longitudinal design are required.

\section{Conclusion}

The patients with neuropathic pain seems more likely to have a poorer disability, intensity of pain and quality of life in chronic LBP. So, the first aim might be differentiating neuropathic pain from non-neuropathic pain while evaluating patients with chronic LBP. Early detection and treatment of neuropathic pain might help improving quality of life and preventing disability in patients with chronic LBP.

\section{Ethics}

Ethics Committee Approval: The study protocol was approved by the Local Research Ethics Committee of Dışkapı Yıldırım Beyazıt Research and Training Hospital (date:25.04.2016 and number: 29/16).

Informed Consent: Informed consent was provided from all the participants.

Peer-review: Internally peer-reviewed.

\section{Authorship Contributions}

Surgical and Medical Practices: B.K., N.T., N.G., E.E., A.C., Concept: N.T., B.K., E.E., Design: N.T., B.K., A.C., Data Collection or Processing: B.K., N.T., N.G., Analysis or Interpretation: B.K., Literature Search: B.K., N.T., N.G., Writing: B.K.

Conflict of Interest: The authors state that none conflict of interest or source of funding was declared.

Financial Disclosure: The authors state that none conflict of interest or source of funding was declared.

\section{References}

1. Krismer M, van Tulder M. Low Back Pain Group of the Bone and Joint Health Strategies for Europe Project. Strategies for prevention and management of musculoskeletal conditions. Low back pain (non-specific). Best Pract Res Clin Rheumatol 2007;21:77-91.
2. Dunn KM, Croft PR. Epidemiology and natural history of low back pain. Eura Medicophys 2004;40:9-13.

3. GBD 2013 Risk Factors Collaborators. Forouzanfar MH, Alexander L, Anderson HR, et al. Global, regional, and national comparative risk assessment of 79 behavioural, environmental and occupational, and metabolic risks or clusters of risks in 188 countries, 1990-2013: a systematic analysis for the Global Burden of Disease Study 2013. Lancet 2015;386:2287-323.

4. Woolf CJ, Bennett GJ, Doherty M, Dubner R, Kidd B, Koltzenburg $M$, et al. Towards a mechanism-based classification of pain? Pain 1998:77:227-9.

5. Treede RD, Jensen TS, Campbell JN, Cruccu G, Dostrovsky JO, Griffin JW et al. Neuropathic pain: redefinition and a grading system for clinical and research purposes. Neurology 2008;70:1630-5

6. Kaki AM, El-Yaski AZ, Youseif E. Identifying neuropathic pain among patients with chronic low-back pain: use of the Leeds Assessment of Neuropathic Symptoms and Signs pain scale. Reg Anesth Pain Med 2005;30:422-8.

7. Berger A, Dukes EM, Oster G. Clinical characteristics and economic costs of patients with painful neuropathic disorders. J Pain 2004;5:143-9.

8. Freynhagen R, Baron R. The evaluation of neuropathic components in low back pain. Curr Pain Headache Rep 2009;13:185-90.

9. Beith ID, Kemp A, Kenyon J, Prout M, Chestnut TJ. Identifying neuropathic back and leg pain: a cross-sectional study. Pain 2011:152:1511-6

10. Mehra M, Hill K, Nicholl D, et al. The burden of chronic low back pain with and without a neuropathic component: a healthcare resource use and cost analysis. J Med Econ 2012;15:245-52.

11. Yucel A, Senocak M, Kocasoy Orhan E, Cimen A, Ertas M. Results of the Leeds assessment of neuropathic symptoms and signs pain scale in Turkey: a validation study. J Pain 2004;(5):427-32.

12. Collins SL, Moore RA, McQuay HJ. The visual analogue pain intensity scale: what is moderate pain in millimetres? Pain 1997;72:95-7.

13. Yakut E, Düger T, Oksüz C, Yörükan S, Ureten K, Turan D, et al. Validation of the Turkish version of the Oswestry Disability Index for patients with low back pain. Spine (Phila Pa 1976) 2004;29:581-5.

14. Dundar P, Fidaner $\mathrm{C}$, Fidaner $\mathrm{H}$. Comparing the Turkish versions of WHOQOL-BREF and SF-36, convergent validity of WHOQOL-BREF and SF-36. Hippokratia 2002;6:37-43.

15. El Sissi W, Arnaout A, Chaarani MW, Fouad M, El Assuity W, Zalzala $\mathrm{M}$, et al. Prevalence of neuropathic pain among patients with chronic low-back pain in the Arabian Gulf Region assessed using the leeds assessment of neuropathic symptoms and signs pain scale. J Int Med Res 2010;38:2135-45.

16. Hassan AE, Saleh HA, Baroudy YM, Abdul-Rahman KI, Najjar MW, Kazi MS, et al. Prevalence of neuropathic pain among patients suffering from chronic low back pain in Saudi Arabia. Neurosciences (Riyadh) 2005;10:51-5.

17. Torrance N, Smith BH, Bennett MI, Lee AJ. The epidemiology of chronic pain of predominantly neuropathic origin. Results from a general population survey. J Pain 2006;7:281-9.

18. Freynhagen R, Baron R, Gockel U, Tölle TR. painDETECT: a new screening questionnaire to identify neuropathic components in patients with back pain. Curr Med Res Opin 2006;22:1911-20.

19. Smart KM, Blake C, Staines A, Thacker M, Doody C. Mechanismsbased classifications of musculoskeletal pain: part 2 of 3 : symptoms and signs of peripheral neuropathic pain in patients with low back ( \pm leg) pain. Man Ther 2012;17:345-51.

20. Becker A, Held H, Redaelli M, Strauch K, Chenot JF, Leonhardt $C$, et al. Low back pain in primary care: costs of care and prediction of future health care utilization. Spine (Phila Pa 1976) 2010;35:1714-20

21. Jensen MP, Chodroff MJ, Dworkin RH. The impact of neuropathic pain on health-related quality of life: review and implications. Neurology 2007;68:1178-82. 